\title{
Differential Expression of Pathogenesis Related Protein Genes in Tomato during Inoculation with A. Solani
}

\author{
Priti Upadhyay ${ }^{1 *}$, Ashutosh Rai $^{2}$, Rajesh Kumar ${ }^{2}$, Major Singh ${ }^{2}$ and Brajesh Sinha ${ }^{1}$
}

${ }^{1}$ Department of Genetics and Plant Breeding, Institute of Agricultural Sciences, Banaras Hindu University, Varanasi, India ${ }^{2}$ Indian Institute of Vegetable Research, Jakhini (shahanshapur), Varanasi, Uttar Pradesh, India

\begin{abstract}
To further increase our understanding of responses in tomato to early blight pathogen, we studied a microarray analysis using Affymetrix Tomato Gene chip array, representing approximately 10,000 genes. Our goal was to understand the pattern of expression of pathogenesis related proteins, which have important roles during interaction between host and pathogen. We found that total thirty two genes in this category showed significant changes in resistant and susceptible genotypes i.e. EC-520061 and CO-3. Amongst these thirty two genes, twenty genes were up regulated in case of resistant genotype whereas no significant up regulation in fold change (FC) was observed in case of the susceptible genotype. This study might be useful for further improvement of resistance in agronomically accepted tomato variety.
\end{abstract}

Keywords: Tomato; A. solani; Expression profiling; Microarray; Pathogenesis related proteins

\section{Introduction}

Tomato (Solanum lycopersicum L.) is one of the most economically important crops worldwide; however, it is susceptible to over 200 pathogens that cause severe destruction for this plant and consequent great reduction in the yield. Many strategies to control these diseases and others on tomato have been developed. However, the major component used in integrated pest management (IPM) studies was the chemical fungicides. The implication of chemical fungicides in soil and water pollution has mandated the search for alternative approaches to disease control management. One of these approaches could be development of resistant cultivar against the disease [1] and for that there is need to know the mechanism behind the resistance reaction i,e. proteins and genes involved in checking the disease in the plant.

Early blight (EB) is one of the most damaging diseases in many tomato production areas worldwide [2,3] incited by Alternaria solani. It reduces the quality and market value of tomato. This disease becomes serious when the season begins with abundant moisture or frequent rainfall by warm and dry weather which are unfavorable for the host and help rapid disease development. Measures to control the outburst of the diseases include a 3 to 5 year crop rotation, routine application of fungicides, and the use of disease free transplants $[3,4]$. Among the three control measures, fungicide treatments is generally the most effective but they are not economically feasible and might be ineffective when weather conditions are favorable for epidemics. The pathogen is also known to infect tomato fruit on maturity therefore fungicidal spraying during period will effect fruit quality and render it unfit for human consumption due to residual effect of the fungicide. Growing resistant varieties is the most effective and feasible technique for EB management in tomato. Progress in breeding for EB resistance has been, however,limited by the lack of effective resistance genes in cultivated tomato [5-7] and by quantitative expression and polygenic inheritance of the resistance [8-10].

When plant is attacked by pathogens, they defend themselves with an arsenal of both passive and active defense mechanism [11].The passive or pre-existing defense mechanism involves structural barriers or strategically positioned reservoirs of antimicrobial compounds which prevent colonization in the tissue. The active or induced defense mechanism include the hypersensitivity response, the production of phytoalexin, lignifications and the reinforcement of the cell wall, as well as the bio-synthesis of pathogenesis related proteins.

Pathogenesis-related proteins (PRs) are plant species-specific proteins produced in response to infection with viruses, fungi or bacteria. Several monocot and dicot plants have been found to produce PRs through a ubiquitous reaction during pathogen attack [12,13]. They have been associated with systemic acquired resistance and incipient anti-pathogen effects. These pathogenesis related responses and inhibition of fungal growth because of these proteins proved their defensive functions in the plant [14-16].They are produced in large quantities in hypersensitive and resistant reactions.Association of PRs in tissue-specific expression during development, consistent localization in the apoplast and vacuolar compartment, and their differential induction by endogenous and exogenous signaling compounds suggests that many PRs may also be involved in other important functions beside plant defense.

Genes responsible for the expression of pathogenesis related proteins has been significantly improved the resistance against various pathogens in different crops $[17,18]$.Understanding the molecular interaction between the EB pathogen (A. solani) and tomato plant might give more insight into the resistance mechanism of tomato to A. solani. Thus, this study aimed to identify PRs and others genes differentially expressed in the tomato host plant upon attack from the EB pathogen (A. solani).

*Corresponding author: Priti Upadhyay, Department of Genetics and Plant Breeding, Institute of Agricultural Sciences, Banaras Hindu University, Varanasi-221005, India, Tel: +91-9899412624; E-mail: priti.iasbhu@gmail.com

Received: January 16, 2014; Accepted February 03, 2014; Published February 10, 2014

Citation: Upadhyay P, Rai A, Kumar R, Singh M, Sinha B (2014) Differential Expression of Pathogenesis Related Protein Genes in Tomato during Inoculation with A. Solani. J Plant Pathol Microb 5: 217. doi:10.4172/2157-7471.1000217

Copyright: (C) 2014 Upadhyay P, et al. This is an open-access article distributed under the terms of the Creative Commons Attribution License, which permits unrestricted use, distribution, and reproduction in any medium, provided the original author and source are credited. 
Citation: Upadhyay P, Rai A, Kumar R, Singh M, Sinha B (2014) Differential Expression of Pathogenesis Related Protein Genes in Tomato during Inoculation with $A$. Solani. J Plant Pathol Microb 5: 217. doi:10.4172/2157-7471.1000217

\section{Material and Methods}

\section{Plant material}

Two tomato genotypes; EC-520061 resistant to early blight, and CO-3 susceptible to early blight were selected on the basis of their performance against EB pathogen during screening experiment [19] for transcription profiling in order to study their response against early blight. The seeds of these varieties were obtained from Indian institute of Vegetable Research, Varanasi, Uttar Pradesh, India. The plants were grown in growth chamber under temperature-controlled condition at $25^{\circ} \mathrm{C}$.

\section{Preparation of fungal inoculums}

An A.solani isolate obtained from infected tomato leaves in Indian Institute of Vegetable Research, Varanasi was propagated on Potato Dextrose Agar (PDA) in 90-mm Petri dishes. The dishes were incubated at $25^{\circ} \mathrm{C}$ under a cool-white fluorescent diurnal light with $12 \mathrm{~h}$ photoperiod for 10-15 d. A 15-d-old culture was scraped and macerated together in a pestle and mortar. This culture was free from conidia but thickening of conidiogenous hyphae and chlamydo sporelike structures were observed in a 15 dold culture. Before the formation of these structures, cultures did not have their usual aggressiveness and potential for infection. Tomato plants were sprayed with an inoculum $\left(157 \mathrm{cfuml}^{-1}\right)$ to induce infection.

\section{Treatment of tomato plants with $A$. solani inoculum and RNA isolation}

Seeds of the two genotypes, EC-520061 and CO-3, were germinated and transplanted into a small pot with soil and places in the growth chamber. During the late seedling stage (6-7 weeks old), plants were individually inoculated with $A$. solani isolate. All inoculated plants were kept moist by maintaining $>95 \%$ relative humidity $(\mathrm{RH})$ and 20 $25^{\circ} \mathrm{C}$ temperature for $5 \mathrm{~d}$. The plants were closely observed each day after inoculation. After the $5 \mathrm{~d}$ infection period, the $\mathrm{RH}$ was reduced to $\sim 85 \%$ and plants were maintained under $12 \mathrm{~h}$ photoperiod. The $\mathrm{RH}$, light and temperature were controlled by a microprocessor regulated system. Plants were individually evaluated for disease symptoms after $7 \mathrm{~d}$ of inoculation. The stress treatments were performed on resistant and susceptible tomato genotypes in three biological replications. The experiment was conducted in reference design, where respective tissues from unstressed plants served as control. The samples for RNA isolation was collected at $24 \mathrm{~h}$ after inoculation and kept at $-80^{\circ} \mathrm{C}$ till
RNA isolation was performed. RNA was isolation using TRIZOL method using manufactures protocol (Invitrogen, USA).

\section{Expression profiling and data analysis}

Affymetrix gene expression kit (Affymetrix, USA) was used for profiling of tomato genome in response to

A. solani infection. Raw microarray data were analyzed to find genes with significantly different expression profiles under early blight stress relative to control conditions. The data was analyzed using Gene Spring 10.1 GX software from Agilent Technologies, Inc. 3501 Stevens Creek Blvd. Santa Clara, CA 95052 USA.

\section{Microarray validation: quantitative real-time RT-PCR analysis}

The total RNA was isolated using TRIZOL (Invitrogen, USA). First strand cDNA for each sample was synthesized by using Superscript ${ }^{\mathrm{TM}} \mathrm{III}$ first-strand synthesis system for RT- PCR (Invitrogen, Carlsbad, CA, USA) following the manufacturer's instructions. Primers for quantitative real-time RT-PCR were designed using web based primer designing tool from IDT (http://eu.idtdna.com/Scitools/Applications/ Primerquest/default.aspx). The sequences of all primers are enlisted in the table 1 .

cDNA of each sample was diluted to $200 \mathrm{ng \mu l}^{-1}$ before amplification. The mRNA expressionlevels of selected probes were analyzed by quantitative real-time PCR (qPCR) using iQ-SYBR Green Supermix (Bio-Rad, CA, USA) according to the manufacturer's protocols on iQ5 thermo cycler (Bio-Rad, CA, USA) with iQ5Optical System Software version 2.0 (Bio-Rad, CA, USA). For calculation of the threshold cycle $\left(\mathrm{C}_{\mathrm{T}}\right)$ values, the auto- $\mathrm{C}_{\mathrm{T}}$ function was used. Each sample was analysed in three technical replicates and for further calculations, the mean value of each triplicate was used. To normalize the target gene expression, the difference between the $\mathrm{C}_{\mathrm{T}}$ of the target gene and the $\mathrm{C}_{\mathrm{T}}$ of Actin (constitutive control) for the respective template was calculated $\left(\Delta \mathrm{C}_{\mathrm{T}}\right.$ value). To calculate fold changes (FC) in gene expression, the $\Delta \mathrm{C}_{\mathrm{T}}$ value was calculated as follows: $\Delta \mathrm{C}_{\mathrm{T}}=\mathrm{C}_{\mathrm{T}}$ (target gene) $-\mathrm{C}_{\mathrm{T}}$ (constitutive control gene). Relative transcript levels were calculated as: $1000 \times 2^{-\triangle \mathrm{CT}}$.

\section{Results}

To identify host responses toA. Solani infection, we analyzed the expression profiles of 10,308 genes represented on the Affymetrix Tomato Genome Array Gene Chip. After $24 \mathrm{~h}$ of inoculation of plants

\begin{tabular}{|c|c|c|}
\hline & Forward Primer & Reverse Primer \\
\hline \multicolumn{3}{|l|}{ Down regulated Genes } \\
\hline Pathogenesis related protein (PRB-1) & GCAGACTCATACACTCTGGTGG & ACTCCATTGCACGTGTTCGCAG \\
\hline Auxin response factor 2 (ARF-2) & TCGCTACAGATGCAGCGTGTTCTA & TGAGCCCTCAGCAACAGAAGAAGT \\
\hline Salicylic acid binding protein-2 (SAB-2) & GGCTGCTTTCATGCCTGATTCTGT & AGCTTGTGAGCCAAGAACTTTGGG \\
\hline Peroxidase (PA-2) & TGGAGGTCCAACATGGCAAGTTCT & TGCCACATCTTGCCCTTCCAAATG \\
\hline Gibberellin 20-oxidase-1 (20 ox-1) & GGGCCTCATTGTGATCCAACATCA & GGAACGCCATTCATCGTCCACAAA \\
\hline Abscission polygalacturonase (TAPG-2) & TGCATCTCTATTGGCCCTGGAACT & CCCAACTCTTGTTGTTTCCAGCCT \\
\hline Lipid binding (LADH-SF) & АТССАТСССАССАСАСТСGТСАAT & TCCATGTCAAGTCACTCCCAGTGT \\
\hline \multicolumn{3}{|l|}{ Up regulated Genes: } \\
\hline Ethylene-responsive transcription factor 3 (RAP-2) & AAAGAACCATCTGTGGCGTGTGAG & CGAATCTTGTAAGCGGCTTGGTCA \\
\hline Xyloglucan endotransglycosylase (XET-2) & TGGAGGAGATTCTGCTGGTGTTGT & TCTGTCTCCTTTGCCTCCTGTGAA \\
\hline Class IV chitinase (CHI-14) & ATGTCACGCATGAGACTGGACACT & AATCCTTCCCGGACACACATGGAT \\
\hline $\begin{array}{l}\text { Ascorbate peroxidise } \\
\text { (APX-1) }\end{array}$ & ATGTCACGCATGAGACTGGACACT & AATCCTTCCCGGACACACATGGAT \\
\hline Catalytic hydrolase -2 (ACS-2) & TTCCATCACTGCAGCTTTGCTTCG & TTTGTTTGGGCCAGCTTCTCTCTC \\
\hline
\end{tabular}

Table 1: The nucleotide sequences Primers of Real Time PCR. 
Citation: Upadhyay P, Rai A, Kumar R, Singh M, Sinha B (2014) Differential Expression of Pathogenesis Related Protein Genes in Tomato during Inoculation with $A$. Solani. J Plant Pathol Microb 5: 217. doi:10.4172/2157-7471.1000217

with A. solani, when the infected leaves werenot curled and the only disease symptom detected as the initial appearance of black spots, the leaves were sampled for RNA isolation. A. solani inoculated tomato leaves were compared with those in mock-inoculated plants in three independent biological replicates. Genes showing at least a 2 -fold change were considered as differentially expressed. In this study, we have observed differentially expressed defense related genes (Table2).

\section{Differential expression of pathogenesis related proteins}

Total thirty two genes in category of pathogenesis related proteins involved in defense mechanism to $A$. solani were differentially expressed in this experiment.Amongst these thirty two genes, twenty genes were up regulated in case of resistant genotype whereas no significant up regulation in fold change (FC)was observed in case of the susceptible genotype. The up-regulated genes in the resistant genotype were Arginine decarboxylase (FC 16.29), DnaJ-like protein (FC 12.42), Xyloglucan endo-transglycosylase (FC 11.74), Putative acyl-CoA synthetase (FC 10.59, 7.28), Patatin-like protein 3 (FC10.01), $17.6 \mathrm{kDa}$ class I heat shock protein (FC 8.83), Tuber-specific protein (FC 8.29), Ethylene-responsive late embryogenesis-like protein (FC 7.28), Glutathione S-transferase (FC 6.88), Plastidicaldolase (FC 6.67), Rhodanese-like (FC 6.43), Cytosolic ascorbate peroxidase (FC 6.03), Pathogenesis-related protein-like protein (FC 5.57), Heat shock cognate $70 \mathrm{kDa}$ protein 1 (FC 5.56), $101 \mathrm{kDa}$ heat shock protein (FC 5.24), Unknown proteins (FC 7.96, 5.18), ChaC-like family proteinlike(FC 5.12) and Iron superoxide dismutase (FC 5.01). The change in expression of these genes was insignificant in susceptible genotype.

On the other hand, after $24 \mathrm{hrs}$ of inoculation with A. solani, 12 genes found to be down regulated in the resistant genotypes wereEndobeta-1,4-D-glucanase (FC -2.48), Gibberellin 20-oxidase-1(FC -5.22), Peroxidase (FC -5.24, -7.30), Abscission polygalacturonase (FC -5.51), Aspartic-type endopeptidase/ pepsin A (FC -5.67), Lipid binding protein (FC -5.77), Ethylene-responsive catalase (FC -5.92), Catalytic hydrolase (FC -8.28), Polygalacturonase precursor (FC -10.24), Salicylic acid-binding protein 2 (FC-17.09), Glucan endo-1,3-betaglucosidase precursor (FC -18.63). Interestingly, the three genes (lipid binding protein, gibberellin 20-oxidase-1, and endo-beta-1,4-Dglucanase) were down-regulated in the resistant and up-regulated in the susceptible genotype

\section{Microarray validation}

The microarray data was validated by quantitative Real-time PCRand the relative fold change in expression was analyzed by the $2^{-\Delta \Delta \mathrm{CT}}$ method. The quantification was relative because the gene expression value analyzed was normalized in relation to the expression of internal reference gene (endogenous control) in the same cDNA

\begin{tabular}{|c|c|c|c|c|}
\hline Affymetrix Probe ID & Gene ID & Description & Fold change in resistant genotype & Fold change in susceptible genotype \\
\hline Les.4004.1.S1_a_at & Les.8179 & 17.6 kDa class I heat shock protein & 8.83 & -1.10 \\
\hline Les.3766.1.S1_at & Les.3766 & $\begin{array}{l}\text { Ethylene-responsive late embryogenesis-like } \\
\text { protein }\end{array}$ & 7.28 & -1.69 \\
\hline Les.3125.1.S1_at & Les.3125 & Xyloglucan endotransglycosylase & 11.74 & 1.45 \\
\hline Les.4819.1.S1_at & Les.4819 & Heat shock cognate $70 \mathrm{kDa}$ protein 1 & 5.56 & -1.10 \\
\hline Les.4225.1.S1_at & Les.11471 & Plastidic aldolase & 6.97 & -1.12 \\
\hline LesAffx.3099.1.S1_at & Les.8243 & Putative acyl-CoA synthetase & 10.59 & 1.22 \\
\hline LesAffx.14776.1.S1_at & Les.7742 & Unknown protein & 7.96 & 1.62 \\
\hline LesAffx.3918.1.S1_at & Les.11394 & Cytosolic ascorbate peroxidase & 6.03 & 1.25 \\
\hline LesAffx.47187.1.S1_at & Les.208 & $101 \mathrm{kDa}$ heat shock protein & 5.24 & 1.17 \\
\hline LesAffx.64902.2.S1_at & Les.9517 & ChaC-like family protein-like & 5.12 & 1.02 \\
\hline LesAffx.46815.1.S1_at & Les.5864 & Unknown protein & 5.18 & 1.79 \\
\hline LesAffx.3606.1.S1_at & Les.12361 & Tuber-specific protein & 8.29 & -1.65 \\
\hline Les.2677.1.S1_at & Les.8243 & Putative acyl-CoA synthetase & 7.28 & 1.82 \\
\hline LesAffx.55504.1.S1_at & BG124298 & Pathogenesis-related protein-like protein & 5.57 & 1.63 \\
\hline Les.179.1.S1_at & Les.12505 & Arginine decarboxylase & 16.29 & -2.06 \\
\hline LesAffx.68054.1.S1_at & Les.11984 & DnaJ-like protein & 12.42 & 1.34 \\
\hline Les.2721.2.S1_at & Les.2721 & Rhodanese-like protein & 6.43 & 1.15 \\
\hline Les.1724.3.A1_at & Les.1724 & Glutathione S-transferase & 6.88 & 1.30 \\
\hline Les.4233.2.A1_at & Les.3014 & Iron superoxide dismutase & 5.01 & 1.19 \\
\hline LesAffx.3554.1.A1_at & CK720570 & Patatin-like protein 3 & 10.01 & 1.60 \\
\hline Les.3665.1.S1_at & Les.3665 & Polygalacturonase precursor & -10.24 & 1.10 \\
\hline Les.3647.1.S1_at & Les. 3647 & Abscission polygalacturonase & -5.51 & 1.16 \\
\hline Les.3549.1.A1_at & Les.3549 & Ethylene-responsive catalase & -5.92 & 1.14 \\
\hline Les.1044.1.A1_at & Les.1044 & Catalytic hydrolase & -8.28 & 1.35 \\
\hline LesAffx.39.1.S1_at & Les.6908 & Peroxidase & -5.24 & -1.03 \\
\hline LesAffx.60831.1.S1_at & Les.10237 & Peroxidase & -7.30 & 1.80 \\
\hline LesAffx.62698.2.S1_at & Les.8987 & B-1,3 Glucanase & -18.63 & -1.26 \\
\hline LesAffx.58326.1.A1_at & Les.10796 & Salicylic acid-binding protein 2 & -17.09 & 1.14 \\
\hline LesAffx.51348.1.S1_at & Les.9863 & Aspartic-type endopeptidase/ pepsin A & -5.67 & 1.03 \\
\hline LesAffx.50170.1.S1_at & Les.12226 & Lipid binding protein & -5.77 & 2.51 \\
\hline Les.3732.1.S1_at & Les. 3732 & Endo- $\beta-1,4-D$-glucanase & -2.48 & 5.67 \\
\hline Les.64.1.S1_at & Les.64 & Gibberellin 20-oxidase-1 & -5.22 & 3.75 \\
\hline
\end{tabular}

*The basis of significance is these genes which shows fold change $>2.0$ at $p$-value $<0.05$

Table 2: Differential expression of pathogenesis related genes in resistant (EC-520061) and susceptible (CO-3) genotypes of tomato against $A$. solani. 
sample [20]. In this study, Actin (a housekeeping gene) was used as endogenous control since its expressionremained uniform during the experiments (Table 1).

Amplification of gene-specific products was analyzed by meltingcurve analysis, followed by agarose gel electrophoresis. In the dissociation curves (temperature versus fluorescence), the Tm values of the PCR products ranged between $82.4^{\circ}$ and $88.6^{\circ} \mathrm{C}$ for each target gene, and $89.8^{\circ} \mathrm{C}$ for Actin. During the 40 amplification cycles, neither nonspecific amplification nor primer-dimer peaks were detected, indicating the specificity of the primers tested. The specificity of gene products were confirmed by the presence of one amplicon per primerpair tested by agarose gel electrophoresis.

Further change the data from q-RT PCR was analysed using bar graph (Figure 1) and it showed approximately the same pattern in expression of the genes in susceptible and resistant genotypes as it was observed in expression profiling experiment using microarray. The microarray approach produced accurate picture of differences, with suitable sensitivity to identify differentially regulated transcripts.

\section{Discussion}

Plants have evolved numerous defensive strategies to perceive and cope with aggression by pathogens, including insects and viruses. The domesticated tomato is extremely susceptible to Alternaria solani. Breeding efforts have resulted in the development of resistant lines and commercial cultivars that present ameliorated symptoms and yields and a lower titer of A. solani than susceptible plants [21-24]. Only few studies have been conducted providing limited insight in the molecular background of $A$. solani resistance in tomato.

In the present investigation, the genes that possibly contribute to the establishment of disease resistance in host plant were identified. Role of the pathogenesis related genes either induced or suppressed during the interaction between tomato and the early blight agent A. solani have been described. By a judicious choice of the control treatment and use of the microarray technique, a data have been generated which shows that these genes have played an important role in this interaction. We have compared the patterns of proteins known to be involved in defense-like (PR proteins) responses upon A. solani infection in tomato genotypes EC-520061, resistant to early blight and $\mathrm{CO}-3$ susceptible to early blight, issued from the breeding program.

There are few studies related to the application of microarraytechnique to identify genesexpressed during plantpathogen interactions [29]were the first to publish microarray in studying plant-fungal interactions. Because microarray can provide information aboutpreviously known genes, it is a robust approach for detecting differentially expressed and potentially important genes. On one hand, knowledge of the expression patterns of specific genes can provide important information with regard to genes required for resistance and their function. While on the other hand, it might help to develop suitable molecular markers to identify resistant cultivars and donor varieties as has been shown by Butterfield et al. [30] and Elansky et al. [31].

To understand molecular basis of specific plant-pathogen interactions, it is important to identify the plant genes that respond to the pathogen attack. Most of the PR proteins involved in recognition processes release defense-activating signal molecules from the walls of invading pathogens [32,33]. Study by Takeuchi et al. [34], Ham et al. [35] and Balasubramanian et al. [36] showed that glucanendo $\beta-1$, 3 -glucanase induced in soybean seedlings by infection or chemical stress releases elicitor-active fragments from cell wall preparations of the fungus Phytophthora megasperma f. sp. Glycinea helping to stimulate defense responses in adjacent cells, as well as induce acquired resistance to further infection. However, the glucanendo $\beta-1$, 3-glucanase and PR-2 induction might reduce callose accumulation

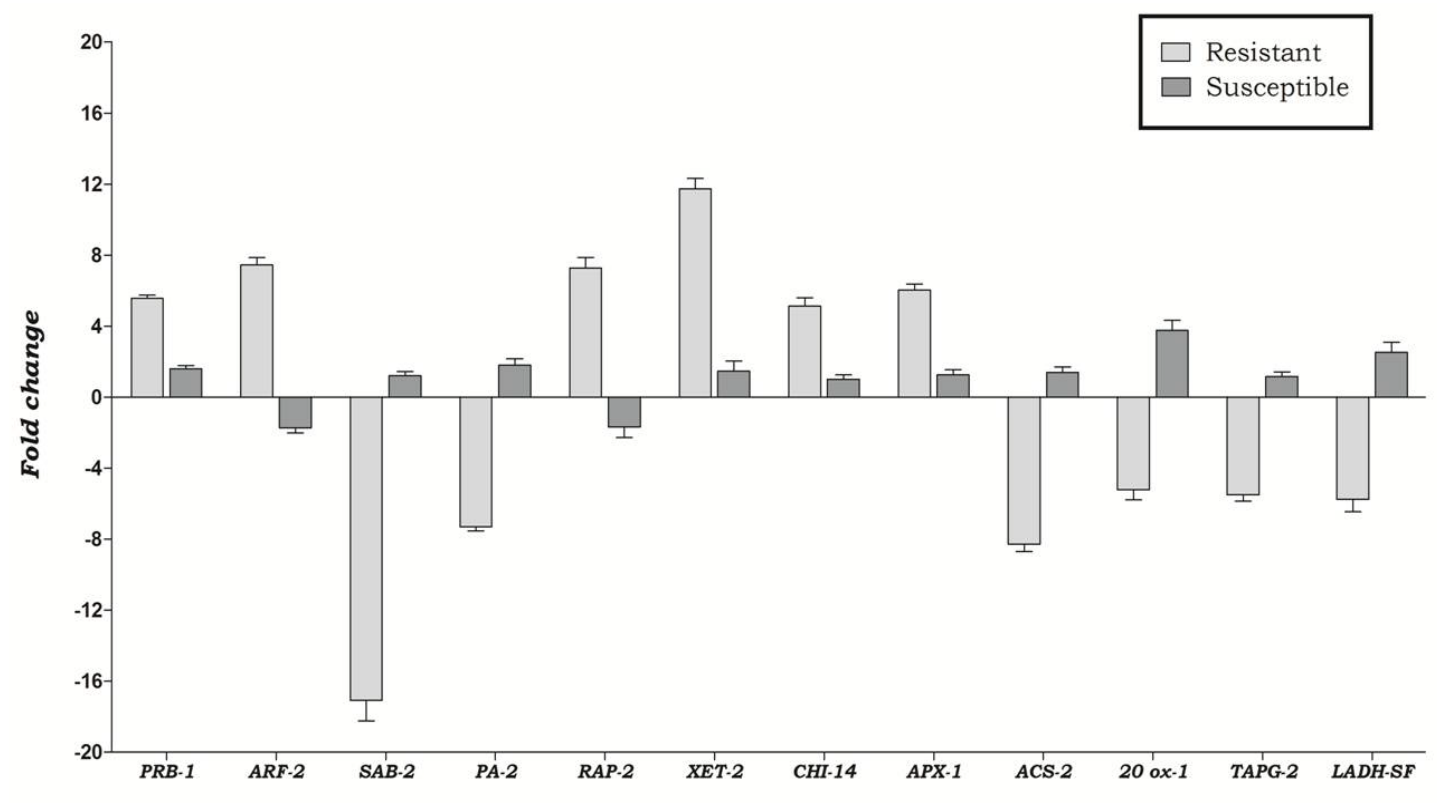

Expression of genes in resistant and susceptible genotypes

Figure 1: Graphical representation of PR proteins genes behavior in resistant and susceptible genotypes of tomato at 24 hrs after inoculation with $A$. solani pathogen. 
against virus infection in tobacco [37-39]. In the present investigation, expression of glucanendo $\beta$-1, 3-glucanase gene was found to be down regulated which is contradictory with the Takeuchi et al. [34] and Ham et al. [35]. It's down regulation may be responsible for blocking the fungal mycelia during penetration of the cells and which results in defense response.

Gene for arginine decarboxylase was found up regulated in the resistant genotype. This result is in accordance with the results observed by Prabhavathi et al. [40]where it has been seen that the egg plant genotypes with more expression of arginine decorboxylase was more resistance to Fusarium wilt. In plants, polyamines can generally be synthesized by the ornithine decarboxylase and arginine decarboxylase pathways.Polyamines (PAs) are small aliphatic amines whose synthesis is tightly regulated. PAs are involved in the modulation of different cellular processes, including functioning of ion channels, chromatin organization, DNA replication, gene transcription, mRNA translation, cell proliferation and apoptosis [41,42]. In the present investigation, polyamine homeostasis might be maintained by induction of the arginine decarboxylase pathway, resulting in the higher hydrogen peroxide accumulation. This ultimately increased resistance of the tomato plants against the fungal pathogen.

The peroxidase enzymes are heme-containing glycoproteins that catalyze the oxidation of a wide range of organic and inorganic substrates by hydrogen peroxide, such as cytochrome c, nitrite, leucodyes, ascorbic acid, indole amines, and iodide ion. Peroxidases occur in numerous isoforms in plants and animals. Plant peroxidases have been implicated in a wide range of physiological processes, such as auxin metabolism, ethylene biosynthesis, lignin formation, respiration, lightmediated processes, growth, andsenescence. In addition, peroxidase activity has been correlated with plant defense against pathogens [4345].

Plant cell wall constitutes one of the first lines defense against pathogen invasion, and peroxidases are key enzymes in the wallbuilding processes. These processes include peroxidase-mediated oxidation of hydroxycinnamyl alcohols into free radical intermediates [46], phenol oxidation [47], polysaccharide cross-linking [48], cross-linking of extensin monomers [49], lignifications, [50,51] and suberization (Quiroga 2000) [51]. Although direct involvement of any one type of peroxidase in defense has not been demonstrated conclusively, extracellular or wall-bound peroxidases have been proposed to enhance resistance by the construction of a cell wall barrier that may impede pathogen ingress and spread [46,52-54]. The accumulation of cell wall-strengthening materials following infection might be expected to correlate with enhanced resistance [45]. The accumulation of lignin and phenolic compounds have been correlated with the resistance in a number of plant-pathogen interactions.

The resistance response in wheat cultivar relude-Sr5, against an a virulent race of the stem rust fungus Puccinia Graminis F. sp. Tritici, was correlated with rapid lignification in penetrated host cells [55]. In tomato, resistance to the fungal pathogen Verticilliumalbo-atrum was correlated with a more rapid deposition of suberin and lignin in a resistant isoline than a susceptible isoline [56,57]. Similarly, infiltration of rice leaves with suspensions of Xanthomonas oryzae Pv. oryzae, the bacterial blight pathogen, caused the deposition of lignin-like polymers at the site of inoculation during resistant interactions. In rice, the spatial and temporal patterns of phenolic polymer deposition were correlated with resistance, that is, the decrease in bacterial multiplication rates and onset of bacteriostasis [58]. Expression of stress-response proteins upon whitefly-mediated inoculation of tomato yellow leaf curl virus in susceptible and resistant tomato plants showed that there was an elevation of peroxidase in susceptible plants but not in resistant plants [59]. The activity of this PR protein may reflect the massive early blight disease symptoms in susceptible leaves compared with the absence of symptoms in resistant tomato plants.

Endo-1, 4-beta-glucanase was down regulated in the resistant genotype by a 2.48 fold change while it was found to be up regulated in the susceptible genotype. Another gene Xyloglucan endotransglycosylase (XET) was found up regulated by 11.74 fold change in the resistant genotype while its fold change was insignificant in the susceptible genotype. These two genes, Endo-1, 4-beta-glucanase and XET, function in cell wall. The gene endo-1, 4-beta-glucanase, here it is not involved in the resistance reaction while the gene XET is accountable for the cleavage of xyloglucan compounds, which are essential for the remodelling of the cell wall, and responsible for the cell wall architecture. In other cases, a direct involvement in the pathogen response could be demonstrated [60]. It was shown that XET was induced in different plants upon aphid infestation, and its role in cell wall modification as part of the plant defence was established. During the hypersensitive response in resistant tomato genotype upon $A$. solani attack, cell wall modifications resulting in the isolation of the affected tissues were also observed [61]. Such modifications prevent feeding by phylloxera as well as secondary infections in the penetration area. We assume that the specific XET up-regulation in resistant genotype observed during interaction between A. solani and tomato, hypersensitive response is part of such cell wall modifications leading to the isolation of the affected tissues.

PR proteins can function either directly on the pathogen or indirectly by creating physical barriers to the fungal infection process or on upstream intrinsic PR signaling. Most of the identified PR proteins act directly to disrupt the fungal/bacterial cell wall (endo-1, 4-beta-glucanase, basic endochitinase and glucanendo- 1, 3-betaglucosidase), or inhibit fungal germination due to ribonuclease activity (hevein-like precursor) [62].It is possible that these proteins participate in the increased tolerance to early blight pathogen A. solani, not only in laboratory conditions but also in the field, by minimizing the damages due to pathogen, insect feeding and viruses [63].

In this study, several genes have been identified that might contribute to disease resistance in the resistant tomato genotypes. The potential application of these genes could be to over-express them in tomato in order to obtain disease-resistant lines. Markers could be developed to select tomato lines that show a high expression of the identified genes [30]. Although disease-resistant transgenic crops are commercially available, future product development seems likely as our current level of understanding of pathogenesis and plant defense improves [64].

In conclusion, the processes that determine the outcome of an interaction between a microbial pathogen and a host plant are complex. Understanding the molecular details of these interactions, such as the pathogen genes required for infection, effective host defense responses and mechanisms by which host and pathogen signaling networks are regulated, might be utilized to design new plant protection strategies. The analysis presented here identified novel pattern of genes for pathogenesis related proteins in stressed tomato that may be important in the response to parasitic threat. Studies of the pathways in which these genes are involved, will give more information about the physiology of early blight disease and may elucidate the mechanisms 
Citation: Upadhyay P, Rai A, Kumar R, Singh M, Sinha B (2014) Differential Expression of Pathogenesis Related Protein Genes in Tomato during Inoculation with A. Solani. J Plant Pathol Microb 5: 217. doi:10.4172/2157-7471.1000217

of tolerance. In any case, the analysis of these genes will contribute to a more comprehensive view of the tomato-A. solani interaction. Nevertheless, further characterization and functional analysis of the genes, identified in this study, can lead to a more comprehensive understanding of tomato-pathogen interactions.

\section{Acknowledgements}

The support from National Project on Transgenic Crops (NPTC), ICAR, New Delhi, India and the Director, Indian Institute of Vegetable Research (IIVR), Varanasi is gratefully acknowledged.

\section{References}

1. Pandey KK, Pandey PK, Kalloo G, Banerjee MK (2003) Resistance to early blight of tomato with respect to various parameters of disease epidemics, J Gen Plant Pathol 69: 364-371.

2. Rotem J (1994) The Genus Alternaria: Biology, Epidemiology, and Pathogenicity. APS Press, St. Paul, MN 326.

3. Sherf AF, MacNab AA (1986) Vegetable Diseases and their Control. (2ndedn), Wiley, New York.

4. Madden L, Pennypacker SP, MacNab AA (1978) FAST: A forecast system for Alternaria solani on tomato. Phytopathology 68: 1354-1358.

5. Vakalounakis DJ (1983) Evaluation of tomato cultivars for resistance to Alternaria blight. Ann ApplBiol 102: 138-139.

6. Poysa V, Tu JC (1996) Response of cultivars and breeding lines of Lycopersicon spp. to Alternaria solani. Canadian Plant Disease Survey 76: 5-8.

7. Banerjee MK, Chhabra ML, Saini PS (1998) Responses of tomato cultivars to Alternaria blight. Tests Agrochemical and Cultivars 19: 50-51.

8. Nash AF, Gardner RG (1988a) Heritability of tomato early blight resistance derived from Lycopersicon hirsutum PI 126445. J Am Soc Hort Sci 113: 264 268.

9. Maiero M, Ng TJ, Barksdale TH (1990a) Combining ability estimates for early blight resistance in tomato. J Am Soc Hort Sci 114: 118-121.

10. Thirthamallappa, Lohithaswa, HC (2000) Genetics of resistance to early bligh (Alternaria solani) Sorauer in tomato (Lycopersicum esculentum L.). Euphytica 113: 187-193.

11. Almagro L, Gómez Ros LV, Belchi-Navarro S, Bru R, Ros Barceló A, et al (2009) Class III peroxidases in plant defence reactions. J Exp Bot 60: 377-390.

12. Somssich IE, Schmelzer E, Kawalleck P, Hahlbrock K (1988) Gene structure and in situ transcript localization of pathogenesis-related protein 1 in parsley. Mol Gen Genet 213: 93-98.

13. Lee OR, Sathiyaraj G, Yu-Jin K, Jun-Gyo I, Woo-Seang K, et al. (2011) Defense Genes Induced by Pathogens and Abiotic Stresses in Panax ginseng C. A. Meyer. J Ginseng Res 35: 1-11.

14. Bol JF, Linthorst HJM, Cornelissen BJC (1990) Plant Pathogenesis-Related Proteins Induced by Virus Infection. Annual Review of Phytopathology 28: 113138.

15. El-kereamy A, El-sharkawy I, Ramamoorthy R, Taheri A, Errampalli D, et al. (2011) Prunus domestica pathogenesis-related protein-5 activates the defense response pathway and enhances the resistance to fungal infection. PLoS One 6: e17973

16. Ebrahim S, Usha K, Singh B (2011) Science against microbial pathogens: communicating current research and technological advances. A. Méndez-Vilas.

17. Uknes S, Mauch-Mani B, Moyer M, Potter S, Williams S, et al. (1992) Acquired resistance in Arabidopsis. Plant Cell 4: 645-656.

18. Ryals J, Uknes S, Ward E (1994) Systemic Acquired Resistance. Plant Physio 104: 1109-1112.

19. UpadhyayP, Singh PC, Sinha B, Singh M, Kumar R, et al. (2009) Sources of resistance against early blight (Alternaria Solani) in tomato (Solanum lycopersicum). Ind J Agri Sci 79: 752-753.

20. Pfaffl MW (2001) A new mathematical model for relative quantification in realtime RT-PCR. Nucleic Acids Res 29: e45.

21. Foolad MR, Lin GY (2001) Heritability of early blight resistance in a Lycopersicon esculentum $\times$ Lycopersicon hirsutum cross estimated by correlation between parent and progeny. Plant Breeding 120: 173-177.

22. Gardner RG (2006) Plum Crimson hybrid tomato and its parents, NC EBR-7 and NC EBR-8. Hort Science 41: 259-260.

23. Foolad MR, Merk HL, Ashrafi H (2008) Genetics, genomics and breeding of late blight and early blight resistance in tomato. Critical Reviews in Plant Sciences 27: 75-107.

24. Gardner RG, Panthee DR (2010) NC 1 CELBR and NC 2 CELBR: Early blight and late blight resistant fresh market tomato breeding lines. Hort Science 45 975-976.

25. Schenk PM, Kazan K, Wilson I, Anderson JP, Richmond T, et al. (2000) Coordinated plant defense responses in Arabidopsis revealed by microarray analysis. Proc Natl Acad Sci U S A 97: 11655-11660.

26. Sasaki Y, Asamizu E, Shibata D, Nakamura Y, Kaneko T, et al. (2001) Monitoring of methyl jasmonate-responsive genes in Arabidopsis by cDNA macroarray: self-activation of jasmonic acid biosynthesis and crosstalk with other phytohormone signaling pathways. DNA Res 8: 153-161.

27. Chen W, Provart NJ, Glazebrook J, Katagiri F, Chang HS, et al. (2002) Expression profile matrix of Arabidopsis transcription factor genes suggests their putative functions in response to environmental stresses. Plant Cell 14 559-574.

28. Vallad GE, Goodman RM (2004) Systemic acquired resistance and induced systemic resistance in conventional agriculture. Crop Science 44: 1920-1934.

29. Baldwin D, Crane V, Rice D (1999) A comparison of gel-based, nylon filter and microarray techniques to detect differential RNA expression in plants. Curr Opin Plant Biol 2: 96-103.

30. Butterfield MK, Rutherford RS, Carson DL, Huckett BI (2004) Application of gene discovery to varietal improvement in sugarcane. South Afr J Botany 70: 167-172.

31. Elansky S, Pobedinskaya M, Kokaeva L, Statsyuk N, Alexandrova A (2012) Molecular identification of the species composition of Russian isolates of pathogens, causing early blight of potato and tomato. In Proceedings of the 13th EuroBlight workshop. PPO-Special Report 15: 151-156.

32. Dixon RA, Harrison MJ, Lamb CJ (1994) Early Events in the Activation of Plant Defense Responses. Annual Review of Phytopathology 32: 479-501.

33. Romeis T (2001) Protein kinases in the plant defence response. Curr Opin Plant Biol 4: 407-414.

34. Takeuchi Y, Yoshikawa M, Takeba G, Tanaka K, Shibata D, et al. (1990) Molecular Cloning and Ethylene Induction of mRNA Encoding a Phytoalexin Elicitor-Releasing Factor, beta-1,3-Endoglucanase, in Soybean. Plant Physio 93: 673-682.

35. Ham KS, Wu SC, Darvill AG, Albersheim P (1997) Fungal pathogens secrete an inhibitor protein that distinguishes isoforms of plant pathogenesis-related endo-ß-1, 3-glucanases. Plant Journal 11: 169-179.

36. Balasubramanian V, Vashisht D, Cletus J, Sakthivel N (2012) Plant ß-1,3 glucanases: their biological functions and transgenic expression against phytopathogenic fungi. Biotechnol Lett 34: 1983-1990.

37. Iglesias VA, Meins F Jr (2000) Movement of plant viruses is delayed in beta-1,3-glucanase-deficient mutant showing a reduced plasmodesmatal size exclusion limit and enhanced callose deposition. Plant J 21: 157-166.

38. Shetty NP, Jensen JD, Knudsen A, Finnie C, Geshi N, et al. (2009) Effects of beta-1,3-glucan from Septoria tritici on structural defence responses in wheat. J Exp Bot 60: 4287-4300.

39. Kathiria P, Sidler C, Golubov A, Kalischuk M, Kawchuk LM, et al. (2010) Tobacco mosaic virus infection results in an increase in recombination frequency and resistance to viral, bacterial, and fungal pathogens in the progeny of infected tobacco plants. Plant physiology 153: 1859-1870.

40. Prabhavathi VR, Rajam MV (2007) Polyamine accumulation in transgenic eggplant enhances tolerance to multiple abiotic stresses and fungal resistance. Plant Biotechnology 24: 273-282.

41. Datta SK, Muthukrishnan S (1999) Pathogenesis-related proteins in plants. CRC Press LLC.

42. Childs AC, Mehta DJ, Gerner EW (2003) Polyamine-dependent gene expression. Cell Mol Life Sci 60: 1394-1406. 
Citation: Upadhyay P, Rai A, Kumar R, Singh M, Sinha B (2014) Differential Expression of Pathogenesis Related Protein Genes in Tomato during Inoculation with $A$. Solani. J Plant Pathol Microb 5: 217. doi:10.4172/2157-7471.1000217

43. Ramamoorthy V, Raguchander T, Samiyappan R (2002) Induction of defenserelated proteins in tomato roots treated with Pseudomonas fluorescens $\mathrm{Pf} 1$ and Fusarium oxysporum f. sp. Lycopersici. Plant and Soil 239: 55-68.

44. Wu G, Shortt BJ, Lawrence EB, Leon J, Fitzsimmons KC, et al. (1997) Activation of Host Defense Mechanisms by Elevated Production of $\mathrm{H}_{2} \mathrm{O}_{2}$ in Transgenic Plants. Plant Physiol 115: 427-435.

45. Ahuja I, Kissen R, Bones AM (2012) Phytoalexins in defense against pathogens. Trends Plant Sci 17: 73-90.

46. Ravi I, Sharma V (2011) Peroxidase Activity and Hydrogen Peroxide Production in Vigna aconitifolia Leaves Infected with Macrophomina phaseolina, Vegetos 24: 71-76.

47. Kärkönen A, Fry SC (2006) Effect of ascorbate and its oxidation products on $\mathrm{H}_{2} \mathrm{O}_{2}$ production in cell-suspension cultures of Picea abies and in the absence of cells. J Exp Bot 57: 1633-1644.

48. Oudgenoeg G (2004), Peroxidase catalyzed conjugation of peptides, proteins and polysaccharides via endogenous and exogenous phenols, Ph.D. thesis.

49. Passardi F, Cosio C, Penel C, Dunand C (2005) Peroxidases have more functions than a Swiss army knife. Plant Cell Rep 24: 255-265.

50. Walter MH (1992) Regulation of lignification in defense in Genes Involved in Plant Defense. Boller T, Meins F (Eds.), Springer-Verlag. New York.

51. Quiroga M, Guerrero C, Botella MA, Barceló A, Amaya I, et al. (2000) A tomato peroxidase involved in the synthesis of lignin and suberin. Plant Physiol 122 $1119-1127$.

52. Wang X, Dyer JH, Zheng L (1993) Purification and immunological analysis of phospholipase $D$ from castor bean endosperm. Arch Biochem Biophys 306: 486-494.

53. Thordal-Christensen H, Zhang Z, Wei Y, Collinge DB (1997) Subcellular localization of $\mathrm{H}_{2} \mathrm{O}_{2}$ in plants: $\mathrm{H}_{2} \mathrm{O}_{2}$ accumulation in papillae and hypersensitive response during the barley-powdery mildew interaction. Plant Journal 11: 1187-1194.
54. Underwood W (2012) The plant cell wall: a dynamic barrier against pathogen invasion. Front Plant Sci 3: 85.

55. Walter S, Nicholson P, Doohan FM (2010) Action and reaction of host and pathogen during Fusarium head blight disease. New Phytol 185: 54-66.

56. Robb J, Powell DA, Street PFS (1987) Time course of wall-coating secretion in Verticillium-infected tomatoes. Physiol Plant Pathol 31: 217-226.

57. Wulff JA, Buckman KA, Wu K, Heimpel GE, White JA (2013) The endosymbiont Arsenophonus is widespread in soybean aphid, Aphis glycines, but does not provide protection from parasitoids or a fungal pathogen. PLoS One 8: e62145.

58. Reimers PJ, Leach JE (1991) Race-specific resistance to Xanthomonas oryzae pv. oryzae conferred by bacterial blight resistance gene Xa-10 in rice Oryzae sativa involves accumulation of a lignin-like substance in host tissues. PhysiolMol Plant Pathol 38: 39-55.

59. Gorovits R, Czosnek H (2008) Expression of stress gene networks in tomato lines susceptible and resistant to Tomato yellow leaf curl virus in response to abiotic stresses. Plant Physiol Biochem 46: 482-492.

60. Divol F, Vilaine F, Thibivilliers S, Amselem J, Palauqui JC, et al. (2005) Systemic response to aphid infestation by Myzus persicae in the phloem of Apium graveolens. Plant Mol Biol 57: 517-540.

61. El-nadi, MF Schröder, MB (2003) Cytology of the hypersensitivity reaction in Rootstocks - Improvement of rootstock breeding. Acta Hortic 617: 17-23.

62. Caporale C, Di Berardino I, Leonardi L, Bertini L, Cascone A, et al. (2004) Wheat pathogenesis-related proteins of class 4 have ribonuclease activity. FEBS Lett 575: 71-76.

63. Shewry PR, Lucas JA (1997) Plant proteins that confer resistance to pest and pathogens. Adv Bot Res 26: 135-192.

64. Stuiver $\mathrm{MH}$, Custers $\mathrm{JH}$ (2001) Engineering disease resistance in plants. Nature 411: 865-868. 